2021-07-21

\title{
Adaptable and Reusable Educational 'bricks' for Teaching Computer Science Ethics
}

\author{
Andrea Curley \\ Technological University Dublin, Andrea.F.Curley@TUDublin.ie \\ Damian Gordon \\ Technological University Dublin, Damian.X.Gordon@TUDublin.ie \\ Ioannis Stavrakakis \\ Technological University Dublin, ioannis.stavrakakis@tudublin.ie
}

See next page for additional authors

Follow this and additional works at: https://arrow.tudublin.ie/scschcomcon

Part of the Computer Sciences Commons

\section{Recommended Citation}

Curley, Andrea; Gordon, Damian; Stavrakakis, Ioannis; Becevel, Anna; Gibson, J.P.; and O'Sullivan, Dympna, "Adaptable and Reusable Educational 'bricks' for Teaching Computer Science Ethics" (2021). Conference papers. 365.

https://arrow.tudublin.ie/scschcomcon/365

This Other is brought to you for free and open access by the School of Computer Sciences at ARROW@TU Dublin. It has been accepted for inclusion in Conference papers by an authorized administrator of ARROW@TU Dublin.

For more information, please contact arrow.admin@tudublin.ie, aisling.coyne@tudublin.ie, gerard.connolly@tudublin.ie.

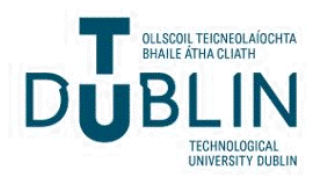




\section{Authors}

Andrea Curley, Damian Gordon, loannis Stavrakakis, Anna Becevel, J.P. Gibson, and Dympna O'Sullivan

This other is available at ARROW@TU Dublin: https://arrow.tudublin.ie/scschcomcon/365 


\title{
ADAPTABLE AND REUSABLE EDUCATIONAL 'BRICKS' FOR TEACHING COMPUTER SCIENCE ETHICS
}

\author{
A. Curley ${ }^{1}$, D. Gordon ${ }^{1}$, I. Stavrakakis ${ }^{1}$, A. Becevel ${ }^{1}$, J.P. Gibson ${ }^{2}$, D. \\ O'Sullivan ${ }^{1}$ \\ 1 Technological University Dublin (IRELAND) \\ ${ }^{2}$ Telecom Sudparis (FRANCE)
}

\begin{abstract}
Within the Computer Science community, many ethical issues have emerged as significant and critical concerns. In this paper we present the concept of adaptable and re-usable educational bricks for the teaching ethics to Computer Science students. The importance of integrating ethical aspects into Computer Science programmes has been highlighted by many scholars [1, 2, 3] . For example in [1] Grosz et al. argue that modern technology cannot be considered "value-neutral", that it can have unplanned consequences and that Computer Science students should be trained to identify the potential harmful effects of the technologies they help develop. We are also inspired by the research of Chuck Huff and C Dianne Martin [4] which places emphasis on empathy, and students imagining the consequences of their own work and actions.
\end{abstract}

The research presented in this paper is taking place in the content of the Ethics4EU project, an Erasmus+ project that aims to provide a central repository of useful re-usable/adaptable education bricks for the teaching of digital ethics, following an "open" model, e.g. [5], such as seen with the creative commons approach. This platform will manage teaching materials following good software engineering practices - as outlined in [6] for improved maintainability and sustainability. We use a standard template for the development of educational bricks with 6 subsections. These are pre-requisites, learning objectives (ethical, computing and transverse), teaching materials, evaluation approach(es), support material (for teachers and students), and links to other bricks. In this paper we describe our approach to developing educational 'bricks' using a one of the developed bricks - learning resources for teaching the topic of dark patters - to demonstrate the concept. Dark patterns are duplicitous user interfaces that trick the user into either sharing more information than they intend to, or spending more money than they want to. We also outline an evaluation framework for testing the developed educational content (bricks) that draws on standard instruments such as LORI (Learning Object Review Instrument), TAM (the Technology Assessment Model) as well reflections from the teacher and student feedback.

References:

[1] Grosz, B. J., Grant, D. G., Vredenburgh, K., Behrends, J., Hu, L., Simmons, A., \& Waldo, J. (2019). Embedded EthiCS: integrating ethics across CS education. Communications of the ACM, 62(8), 54-61.

[2] Harris, A. L., Lang, M., Yates, D., \& Kruck, S. E. (2019). Incorporating ethics and social responsibility in IS education. Journal of Information Systems Education, 22(3), 1.

[3] Weikle, D. A. B. (2018). Teaching the code and ethics in computing. ACM SIGCAS Computers and Society, 48(1), 9-11.

[4] Chuck Huff and C Dianne Martin (1995). Computing consequences: a framework for teaching ethical computing. Communications of the ACM, 38(12):75-84, 1995.

[5] liyoshi, Toru, and M. S. V. Kumar (2010). Opening up education: The collective advancement of education through open technology, open content, and open knowledge. The MIT Press, 2010.

[6] J. Paul Gibson, and Jean-Luc Raffy (2011). "A "Future-Proof" Postgraduate Software Engineering Programme: Maintainability Issues." The Sixth International Conference on Software Engineering Advances (ICSEA 11), Barcelona, Spain (October 2011). 2011.

Keywords: Computer Science Ethics, Case Studies, Dark Patterns. 